\title{
МЕТОДОЛОГИЧЕСКИЕ ПОДХОДЫ К ПРОЦЕССУ ФОРМИРОВАНИЯ КОММУНИКАТИВНОЙ КОМПЕТЕНТНОСТИ СТУДЕНТОВ СПО В УСЛОВИЯХ ДИСТАНЦИОННОГО ОБУЧЕНИЯ
}

\section{METHODOLOGICAL APPROACHES TO THE PROCESS OF FORMING THE COMMUNICATIVE COMPETENCE OF SECONDARY VOCATIONAL EDUCATION STUDENTS IN THE CONTEXT OF DISTANCE LEARNING}

\section{A. Nazarenko S. Mullina}

Summary: The current state of secondary vocational education is characterized by the development of training with the use of distance learning technologies. The educational process is increasingly involved in the information and educational environment, which affects the requirements for both educational workers and students of vocational education. At the same time, the rapid development of information technology requires from modern society an appropriate pace of communication. A modern professional must have a set of competencies that contribute to successful professional activity, which directly depends on his communication skills. This study examines modern approaches to the process of forming students' communicative competence. The formation of communicative competence is facilitated by classes in the humanitarian cycle, which form the skill of productive communication. The considered methods of forming students' communicative competence were tested at the OGBPOU "Ulyanovsk College of Urban Planning and Law" during periods of distance learning for students in connection with the introduction of measures to ensure sanitary and epidemiological well-being in the territory of the Russian Federation in connection with the spread of a new coronavirus infection (COVID-19) [14]. The experience gained has proved the relevance of the considered approaches and the possibility of successful application of the investigated methods of forming the communicative competence of secondary vocational education students in the context of distance learning.

Keywords: communicative competence, distance learning, communicative-activity approach, system approach, competence-based approach.

\author{
Назаренко Александр Владимирович \\ Д.п.н., к.э.н., ФГБОУ ВО «Ульяновский государственный \\ педагогический университет имени И.Н. Ульянова» \\ avnokn@mail.ru \\ Муллина Светлана Эриковна \\ Аспирант, ФГБОУВО «Ульяновский государственный \\ педагогический университет имени И.Н. Ульянова»
} s.e.mullina@gmail.com

Аннотация: Современное состояние среднего профессионального образования характеризуется развитием обучения с применением дистанционных образовательных технологий. Учебный процесс все более интенсивно вовлекается в информационно-образовательную среду, что влияет на требования, предъявляемые как к работникам образовательной сферы, так и к студентам СПО. В то же время стремительное развитие информационных технологий требует от современного общества соответствующего темпа коммуникации. Современный профессионал должен обладать набором компетенций, способствующих успешной профессиональной деятельности, которая напрямую зависит от его коммуникативных способностей. Данное исследование рассматривает современные подходы к процессу формирования коммуникативной компетентности студентов. Формированию коммуникативной компетентности способствуют занятия гуманитарного цикла, которые формируют навык продуктивного общения. Рассмотренные приемы формирования коммуникативной компетентности студентов были апробированы в ОГБПоУ «Ульяновский колледж градостроительства и права» в периоды дистанционного обучения студентов в связи с введением мер по обеспечению санитарно-эпидемиологического благополучия на территории РФ в связи с распространением новой коронавирусной инфекции (COVID-19) [14]. Полученный опыт доказал актуальность рассмотренных подходов и возможность успешного применения исследованных приемов формирования коммуникативной компетентности студентов СПО в условиях дистанционного обучения.

Ключевые слова: коммуникативная компетентность, дистанционное обучение, коммуникативно-деятельностный подход, системный подход, компетентностный подход. 
емым специалистам сферы образования: преподаватель СПО должен уметь использовать дистанционные образовательные технологии [с. 8, 10]. Согласное мнению российского психолога Зимней И. А., умение вступать в социальное взаимодействие, общаться в устной и письменной формах, владение возможностями информационных технологий относятся к числу ключевых компетенций современного человека. [с. 12-13, 4].

Современная система образования способствует формированию у обучающихся всех необходимых компетенций, которые помогут им стать успешными и востребованными на рынке труда.

Вопрос формирования коммуникативной компетентности обучающихся является объектом изучения не только педагогики, но и психологии, философии, социологии и ряда других наук.

С проблемой формирования коммуникативной компетентности тесно связано понятие «активное взаимодействие» [c. 304, 9]. Согласно исследованиям отечественных лингвистов (Щерба Л.В., [19], Виноградов В.В. [1], Звегинцев В.А. [3]), формированию коммуникации человека способствует развитие речевой деятельности. Современные исследователи (Лазарева Н.М. [6], Тесликова Н.Н. [12], Уварцева Т.С., Жаксыбаева Г.Д. [13], Глухих Н.В., Миронова А.А. [2]) отмечают тесную связь процесса формирования навыков коммуникативной компетентности с процессом формирования навыков общения и развитием творческого потенциала обучающихся. По мнению кандидата педагогических наук Тесликовой Н.Н., «успешность профессиональной деятельности во многом определяется коммуникативной компетентностью, то есть способностью к эффективному общению» [12] Исследователи демонстрируют эффективность формирования навыков речевого и письменного общения, способствующих раскрытию личности с творческой стороны, на занятиях гуманитарного цикла. На основе методологического анализа работ современных исследователей мы определили, что большой выбор научных трудов относительно методологических подходов к процессу формирования коммуникативной компетентности обучающихся в малой степени касается сферы среднего профессионального образования; еще менее изученным остается вопрос методологических подходов этого же процесса в условиях дистанционного обучения.

Целью нашего исследования является определение методов и приемов в рамках методологических подходов к процессу формирования коммуникативной компетентности на занятиях гуманитарного цикла и возможности их применения в условиях дистанционного обучения. В данном исследовании мы использовали метод анализа научной и методической литературы, а также метод систематизации данных собственного опыта.
Под коммуникативной компетентностью мы понимаем совокупность навыков и умений коммуникативной деятельности: говорение, письмо, слушание и чтение [с. 67 18]. В процесса анализа методологических подходов к процессу формирования коммуникативной компетентности студентов СПО в условиях дистанционного обучения мы опирались на работы современных исследователей, занимающихся проблемой формирования коммуникативной компетентности обучающихся на занятиях гуманитарного цикла (Лазарева Н.М., Тесликова Н.Н., Шевц И.А. [17], а также с использованием инновационных технологий (Уварцева Т.С., Жаксыбаева Г.Д., Глухих Н.В., Миронова А.А., Мачульская И.А.).

Дистанционное обучение понимается нами как процесс взаимодействия обучающихся и преподавателя, находящихся на расстоянии друг от друга. Результатом дистанционного обучения должны стать сформированные у выпускника общие и профессиональные компетенции, необходимые для работы в выбранной им сфере.

Анализ научной и методической литературы выявил ряд методологических подходов к процессу формирования коммуникативной компетентности обучающихся учебных заведений высшего и среднего профессионального звена.

Сторонники коммуникативно-деятельностного подхода к процессу формирования коммуникативной компетентности обучающихся (Лазарева Н.М., Тесликова Н.Н., Уварцева Т.С.) выделяют несколько эффективных методов приемов, способствующих продуктивному общению на занятиях гуманитарного цикла («Культура речи и деловое общение», «Культура речи», «Иностранный язык».

Одним из методов, способствующих раскрытию творческого потенциала обучающихся, является метод проблемно-ситуативного обучения. В качестве приемов данного метода выступают деловые игры, кейс-технологии, дискуссии, а также погружение обучающихся в ситуации с решением лингвистических задач.

Не менее эффективным и действенным является метод моделирования, в ходе которого обучающимся предлагаются задания и упражнения по развитию техники устной и письменной речи, обогащению словарного запаса. Согласно исследованиям Тесликовой Н.Н., формирование коммуникативной компетентности происходит через развитие творческих способностей обучающихся, а они в свою очередь начинаются с умения слушать и анализировать информацию [12]. В качестве приемов, способствующих формированию коммуникативной компетентности обучающихся, исследователь предлагает тренинги, деловые игры, дискуссии, эссе все, что создает обстановку реального общения. 
К числу методов, формирующих коммуникативную компетентность обучающихся современного мира, относятся интерактивные методы. В качестве приемов интерактивного метода выступают все те же деловые игры, дискуссии, конкурсы разного уровня и масштаба, различные проекты и конференции.

В качестве метода системного подхода к процессу формирования коммуникативной компетентности обучающихся, способствующего повышению творческой активности обучающихся, проявлению речевого поведения, выступает метод анализа текста и выступления [15], а также метод контроля процесса формирования культуры общения обучающихся [7]. В качестве приемов данного метода могут выступать участие обучающихся в дебатах, устных выступлениях, решение проблемно-ситуативных задач, беседы с обучающимися и родителями, интервью.

Компетентностный подход к процессу формирования коммуникативных компетенций предлагает метод логического и критического мышления, в ходе которого обучающиеся учатся искать и изучать информацию, размышлять, работать в группе [5]. В рамках данного подхода некоторые исследователи представляют формирование коммуникативной компетентности у обучающихся в трех этапах: коммуникативно-диагностическом, коммуникативно-деятельностном, коммуникативно-рефлексивном - через проведение дискуссий, тренингов [с. $255,8]$.

Перечисленные методы и приемы были апробированы в Ульяновском колледже градостроительства и права на занятиях во время дистанционного обучения. Как показывает опыт, дистанционные образовательные технологии обладают всеми возможностями для использования приемов формирования коммуникативной компетентности студентов СПО во время занятий по дисциплинам: «Русский язык» и «Литература». В качестве средств реализации данных методов и приемов выступила корпоративная платформа Microsoft Teams с целым набором возможностей: онлайн-собрания, оффлайн-задания, интерактивная доска Microsoft Whiteboard, тестовый редактор Microsoft Forms, блокнот OneNote для размещения информации общего пользования.

Как показывает опрос, проведенный среди студентов СПО города Ульяновска, в котором приняло участие 405 человек, 80\% опрошенных довольны учебой в дистанционном формате, 93\% опрошенных поддерживают связь во время дистанционного обучения с преподавателями и одногруппниками, используя возможности сети Интернет, мобильной связи, социальных сетей и специализированных образовательных платформ.

Анализ коммуникативно-деятельностного, системного и компетентностного подходов показал, что методы, используемые в процессе формирования коммуникативной компетентности обучающихся, возможны в условиях дистанционного обучения. Реализация данных методов имеет положительные результаты в условиях дистанционного обучения как для обучающихся, так и для преподавателей. Использование средств дистанционного обучения способствует формированию у обучающихся тех необходимых компетенций, которые важны в профессиональной подготовке выпускника. Современные средства коммуникации позволяют применять рассмотренные методы и приемы формирования коммуникативной компетентности студентов СПО в условиях дистанционного обучения.

\section{ЛИТЕРАТУРА}

1. Виноградов В.В. История русских лингвистических учений: учеб. пособие для филол. специальностей ун-тов / сост. Ю.А. Бельчиков; предисл. Ю. В. Рождественского. - М.: Высш. школа, 1978.- 357 с.

2. Глухих Н.В., Миронова А.А. Приемы формирования коммуникативной компетенции будущего учителя в деловом общении // Вестник Южно-Уральского государственного гуманитарно-педагогического университета. 2019. №4. С. 91-101.

3. Звегинцев В.А. Язык и лингвистическая теория. М.: Эдиториал УРСС, 2001. 248 с.Электронный ресурс https://www.aelib.org.ua/texts/zvegintsev__ language_and_linguistic_theory_ru.htm

4. Зимняя И.А. Ключевые компетенции - новая парадигма результата образования // Эксперимент и инновации в школе. 2009. №2. С. 7 - 14.

5. Калугина 0.А. Формирование коммуникативной компетентности // Финансовый журнал. 2011. №4. С. 179 - 188.

6. Лазарева Н.М. Формирование профессиональной коммуникативной компетенции у студентов вузов посредством применения инновационных технологий на занятиях по дисциплине «Культура речи и деловое общение» // Вестник Марийского государственного университета. 2018. Т. 12. №4. С. 51-54.

7. Лапшова А.В. Системно-функциональный подход к формированию коммуникативной культуры студентов // Проблемы современного педагогического образования. 2019. №65-3. С. 57-59.

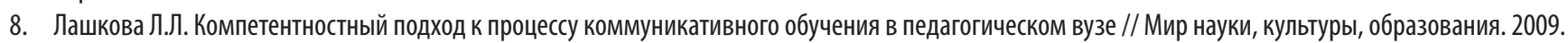
№5. С. $254-257$.

9. Мачульская И.А., Машина А.В., Машин В.Н., Григоров А.Ю. Образовательная деятельность в контексте развития и формирования коммуникативной компетентности курсантов военных вузов в современных условиях// Международный электронный журнал. 2018. №4 (34). С. 301 - 308. 
10. Профессиональный стандарт. Педагог профессионального обучения, профессионального образования и дополнительного профессионального образования. [Электронный ресурс]// Федеральный институт развития образования. URL: https://firo.ranepa.ru/professionalnye-standarty-dlya-pedagogov-spo (дата обращения: 31.10 .21$)$.

11. Распоряжение Правительства РФ от 01 ноября 2013 года 06 утверждении стратегии развития отрасли информационных технологий РФ на $2014-2020$ годы и на перспективу до 2025 года (с изменениями и дополнениями). [Электронный ресурс] // Информационно-правовой портал Гарант.Ру. URL: https://base.garant.ru/70498122/ (дата обращения: 31.10.21).

12. Тесликова Н.Н. Инновационные технологии на занятиях по русскому языку и культуре речи как средство развития коммуникативной компетенции и креативности студентов юридического факультута вуза // Вестник Рязанского государственного университета им. С. А. Есенина. 2014. вып. №1 (42). C. 51-59.

13. Уварцева Т.С., Жаксыбаева Г.Д. Интерактивные методы в процессе формирования профессионально-коммуникативной компетенции // Вестник ТГПу. 2014. №6 (147). С. $76-78$

14. Указ Президента РФ 0 продлении действия мер по обеспечению санитарно-эпидемиологического благополучия населения на территории Российской Федерации в связи с распространением новой коронавирусной инфекции (COVID-19) [Электронный ресурс] // Официальный интернет-портал правовой информации. URL: http://publication.pravo.gov.ru/Document/View/0001202004290001.

15. Халвашин Х.3. Инновационный подход к формированию коммуникативной компетентности // Система ценностей современного общества. 2013. №29.

16. Федеральный государственный стандарт среднего профессионального образования [Электронный ресурс] // ФГОC. URL: https://fgos.ru/search/spo/.

17. Шевц И.А. Профессиональная коммуникативная компетентность выпускника факультета журналистики, ее структура и содержание // Вестник ЮжноУральского государственного университета. Серия: Образование. Педагогические науки. 2010. №12 (188). том 188. С. 117 - 124.

18. Шкроб Н.В. К вопросу о формировании коммуникативной компетентности курсантов высших образовательных учреждений МЧС России // Сибирский пожарно-спасательный вестник. 2018. №2. С.64-69.

19. Щерба Л.В. Языковая система и речевая деятельность / под ред. Л.Р. Зиндер, М.И. Матусевич. - Л.: Наука, 1974. 428 с. [Электронный источник] http://elib.gnpbu.ru/text/scherba_yazykovaya-sistema--deyatelnost_1974/go,8;fs,1/

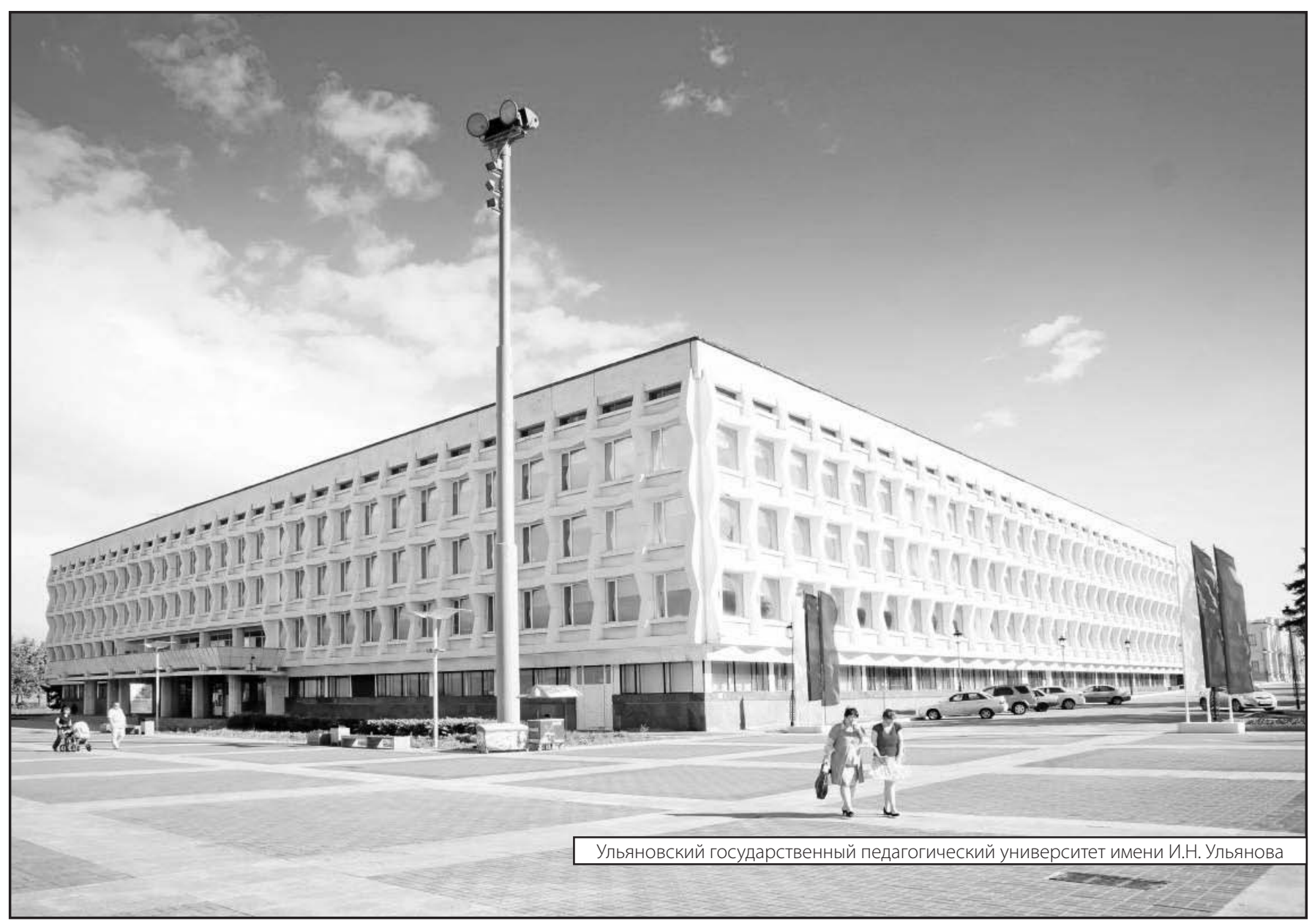

